\title{
Apocorophium acutum (Crustacea: Amphipoda: Corophiidae), Newly Recorded Corophiid Species in Korea
}

\author{
Jongwoo Jung and Won Kim* \\ School of Biological Sciences, Seoul National University, Seoul 151-747, Korea
}

\begin{abstract}
We here report Apocorophium acutum (Chevreux, 1908) with description and illustrations for the first time in Korea. Specimens of present study show morphological differences in ventral processes of peduncular segment 5 of antenna 2 with the same species from Europe and Atlantic coast of North America.
\end{abstract}

Key words: Apocorophium acutum, Amphipoda, Corophiidae, Corophinae

\section{INTRODUCTION}

Apocorophium acutum (Chevreux, 1908) represents almost worldwide distribution from warm temperate to tropical regions (Bousefield, 1973). In the East Asia region, Irie $(1957,1958)$ initially reported this species in adjacent sea of Japan. However, he did not deal with any description or illustration on this species in his works, such that morphological comparison cannot be possible with individuals from other regions. In the present study, we report A. acutum, firstly in Korea with description and illustrations, referring morphological variation.

\section{MATERIALS AND METHODS}

Samples were collected by sieving the washings of oyster and algae beds in the intertidal zone. Specimens were initially fixed and preserved in 5\% formaldehyde solution, then were preserved in $80 \%$ ethyl alcohol in the laboratory. Identification were facilitated by dissection of specimens under a stereomicroscope (Leica MZ8), and mounting the dissected parts on temporary or permanent slide. Dissection and measurement followed the methods of Barnard and Karaman (1991). Temporary mounts were made using glycerine or lactic acid, and semi-permanent mounts were made using polyvinyl lactophenol solution after staining lignin pink dyes. Illustration was made with a compound microscope (Nikon Optiphot) fitted with drawing tube.

\footnotetext{
To whom correspondence should be addressed

Tel: 82-2-880-6695, Fax: 82-2-872-1993

E-mail: wonkim@plaza.snu.ac.kr
}

\section{SYSTEMATIC ACCOUNTS}

Order Amphipoda Latreille, 1816

Suborder Gammaridea Dana, 1852

Family Corophiidae Dana, 1849

Subfamily Corophiinae Bousefield and Hoover, 1997

1*Genus Apocorophium Bousefield and Hoover, 1997

${ }^{2 *}$ Apocorophium acutum (Chevreux, 1908) (Fig. 1)

Corophium acutum Chevreux, 1908, p. 75; Chevreux and Fage, 1925, p. 366, f. 359-374; Schellenberg, 1928, p. 633; Shoemaker, 1934, pp. 26-27; Bousefield, 1973, p. 205, pl. LXIV.2

Apocorophium acutum: Bousefield and Hoover, 1997, pp. 123-125.

Material examined. 10 우오 and $50^{7} \sigma^{7}$ (intertidal zone), Seomyeon (Seocheon) (N36 $\left.9^{\prime} 20^{\prime \prime} \mathrm{E} 126^{\circ} 30^{\prime} 45^{\prime \prime}\right), 21$ Sep. 1998 (J. Jung); 1 우 (intertidal zone), Noryang (Hadong) (N34 $\left.56^{\prime} 54^{\prime \prime} \mathrm{E} 127^{\circ} 51^{\prime} 7^{\prime \prime}\right), 29$ May 1999 (S.H. Kim); 1 우 (oyster bed) and 1 우 (algae bed), Daecheong (Ongjin)

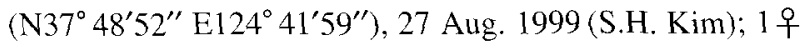
and $1 \sigma^{7}$ (algae bed), Changseon (Namhae) N34 $51^{\prime} 52^{\prime \prime}$ E128 04'20'), 24 Nov, 1999 (J. Jung).

Female. Body short and broad, $2.30 \mathrm{~mm}$ long. Rostrum short, lateral ridge produced (Fig. 1A). Urosome fused, lateral margin setose, uropod 1 and 2 arising ventrally (Fig. $1 \mathrm{~N})$.

Antenna 1 (Fig. 1A) short, $1.71 \mathrm{~mm}$ long, relative length of peduncular segments $1-37: 6: 3$, peduncular segment 1 with two spines near proximal end of inner margin, flagellum about half as long as peduncle, consisting of four segments, last three segments with aesthetasc. Antenna 2 (Fig. 1B) stout and short, $2.12 \mathrm{~mm}$ long, gland cone at peduncular

$1 *$ 이형뱀 옆새우속 (신칭), ${ }^{2 *}$ 빼족이형뱀옆새우 (신칭) 


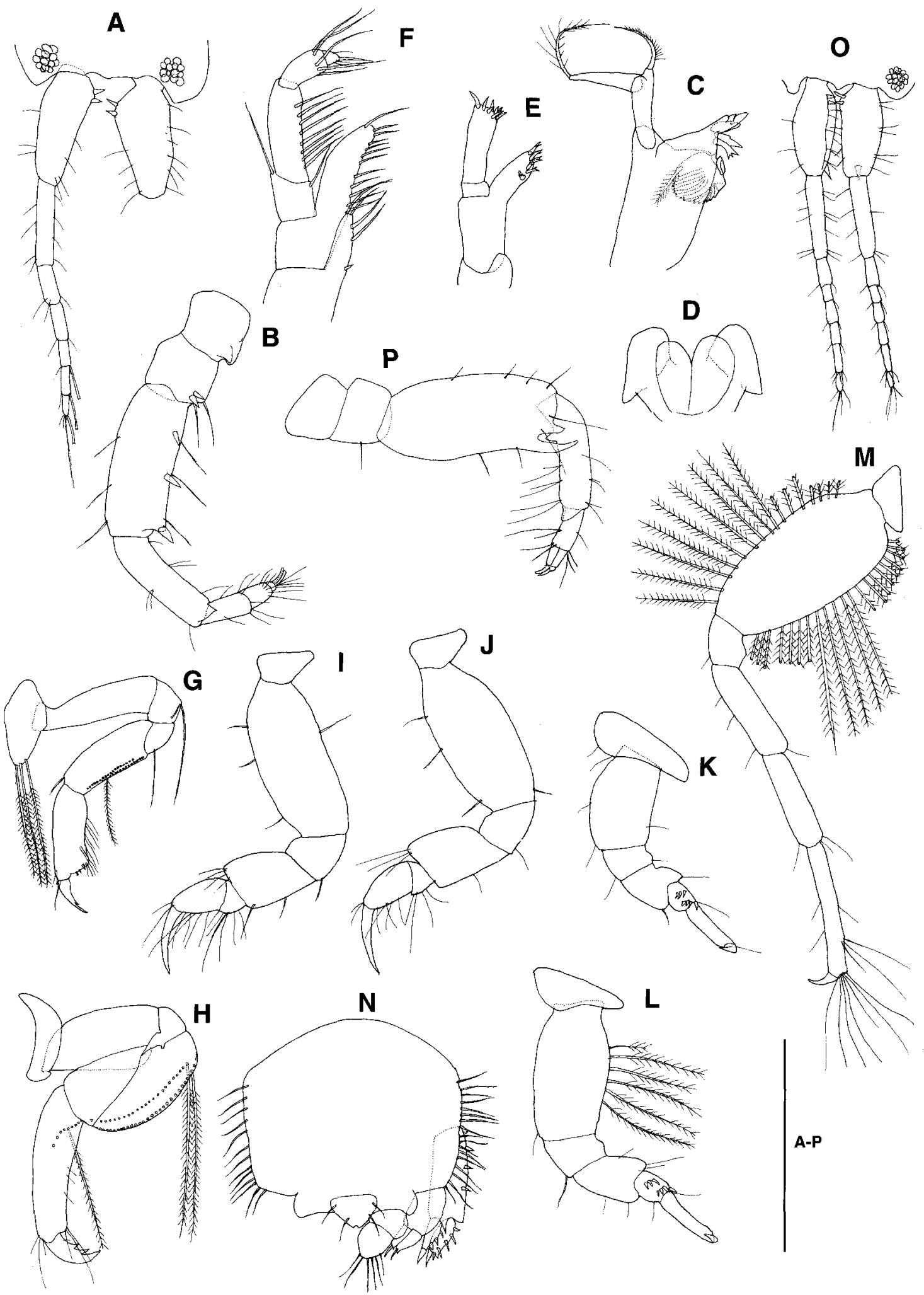

Fig. 1. Apocorophium acutum, fermale. $A$, dorsal view of head and antenna $1 ; B$, antenna 2; $C$, mandible; $D$, lower lip; $E$, maxilla 1 ; F, Maxilliped; G, left gnathopod 1; H, left gnathopod 2; I, left pereopod 3; J, left pereopod 4; $\mathrm{K}$, left pereopod 5; L, left pereopod 6; $\mathrm{M}$, left pereopod $7 ; \mathrm{N}$, urosome, uropods and telson. Apocorophium acutum, male. $\mathrm{O}$, dorsal view of head and antenna $1 ; \mathrm{P}$, antenna 2. Scale bars $=1 \mathrm{~mm}(A, B, G-P), 0.25 \mathrm{~mm}(C-F)$. 
segment 2 short, peduncular segment 3 with two ventrodistal spines and two setae, peduncular segement 4 with two ventromedial spines and one ventrodistal spine, peduncular segment 5 three fourths as long as peduncular segment 4 with a ventrodistal triangular process, flagellum short, 3segmented, terminal segment with two obtuse spines.

Mandible (Fig. 1C) developed, incisor produced inward, with three acute teeth, lacinia mobilis with one tooth and two accessory blades, molar developed, palp composed of two segments, palpal segment 1 with short and bent pinnate seta at distal end, palpal segement 2 as long as palpal segment 1, with long and bent pinnate seta. Lower lip (Fig. 1D), mandibular lobe strong. Maxilla 1 (Fig. 1E), outer plate with six bifid spines, palp short, biarticulate, palpal proximal segment very short, palpal terminal segment with eight spines. Maxilliped (Fig. 1F) inner plate short, outer plate slender, palp composed of four segment, palp segment 4 with spine on apex.

Gnathopod 1 (Fig. 1G), coxa 1 oval, slightly produced anteior and posterior end, with three long pinnate setae at anterior end, basis about one fifth as long as gnathopod 1, gradually increasing in width apically, posterior margin rounded, ischium short, expanded anterodistally, posterodistal margin surrounded by several long setae, merus as long as ischium, posterodistal end with one simple setae, carpus slightly shorter than basis, anterior margin rounded, anterodistal margin with one simple seta, posterior margin with two longitudinal rows of plumose setae, propodus slender, slightly shorter than carpus, posterior margin with several setae, palm slightly oblique, slightly rounded posteriorly, with several spines and setae, dactylus slightly extending beyond palm, with a weak posterior marginal tooth.

Gnathopod 2 (Fig. 1H), coxa 2 small, crescent-shaped, dorsal margin concave, posterodistal margin tapered, basis slightly increasing in width, ischium short, stout, rounded posteriorly, merus as long as basis, rounded posteriorly, with many long plumose setae in two rows, not occluding posterodistal margin of carpus, carpus about eight elevenths as long as propodus, increasing in width, posterodistal end with one plumose setae, gradually narrower toward apex in width, gently rounded anteroproximally, inner proximal part with one oblique row of nine long plumose setae, dactylus with two posterodistal teeth.

Pereopod 3 (Fig. 1I), coxa 3 small, anterior transverse, posterior tapered, ventral margin rounded, basis about one third as long as pereopod 3, anterior margin rounded, with three short setae, posterior marin slightly rounded, with one short seta, ischium short, as long as wide, merus about half as long as basis, gradually extending apically, anterodistal end with three setae, carpus very short, partly overhung anteriorly by merus, posterior margin with five setae, propodus gradually decreasing in width apically, dactylus slightly longer than propodus, curved.

Pereopod 4 (Fig. 1J), similar in size and shape with pereopod 3.

Pereopod 5 (Fig. 1K), coxa 5 dorsoventrally depressed, slightly narrowed posteriorly, anterior and posterior margin rounded, ventral margin slightly concave, basis about one third as long as pereopod 5, anterior marin with two short setae, posterioir margin with one short seta, ischium one fourth as long as basis, slightly protruded at posteromedian region, merus about two times longer than ischium, slightly expanded at posterodistal end, carpus half as long as merus, posteroproximal margin with one transverse row of three spines, posterodital end surrounded by four spines, propodus two times longer than carpus, slender, uniform in width, dactylus small, curved.

Pereopod 6(Fig. 1L), overall similar to pereopod 5, except slightly longer than pereopod 5 , with six plumose setae at posterior margin of basis.

Pereopod 7 (Fig. 1M) as long as body length, $2.92 \mathrm{~mm}$ long, coxa small, ventrally rounded, dorsally straight, basis about one third as long as pereopod 7 , anterior and posterior margin expanded, anterior margin with 16 long plumose setae, posterior margin with 21 long plumose setae, ischium short, slightly protruded posteriorly, anterodistal end with one short seta, merus about half as long as basis, uniform in width, carpus as long as merus, propodus three fourths as long as basis, narrower than carpus, uniform in width, anterior margin with two setae, posterior margin with four setae, distal end with seven long setae, dactylus short, curved.

Uropods (Fig. 1N), uropod 1 not extending beyond uropod 2 , peduncle two times as long as rami, outer margin with four spines, outer ramus with five spines and one stout spine on apex, inner ramus with three spines on outer margin, one stout spines on apex, uropod 2 three fourths as long as peduncle of uropod 1, peduncle about twice longer than rami, exterior margin slightly inflated, rami gradually narrowing apically, spine on each apex, uropod 3 slightly shorther than uropod 2, uniramous, peduncle shorter and slightly broader than ramus, outer margin rounded, ramus large with six distal setae.

Telson (Fig. 1N) fleshy, small, broad, subtriangular, armed with four short setae.

Male. Body, $2.80 \mathrm{~mm}$ long, similar to female except followings. Rostrum sligtly more produced than female, antenna 1 with a spine on ventrodistal margin (Fig. 1O), antenna 2 pediform, stronger than female, peduncular segment 4 with a bidentate distal process, peduncular segment 5 with one tubercle on ventroproximal region (Fig. 1P).

Distribution. Nearly cosmopolitan in warm temperate-tropical regions. 
Remarks. Chevreux (1908) firstly recorded this species without any description of male individual. Later, Chevreux and Fage (1925) described male with a few illustrations. Bousefield (1973) provided detailed illustrations and description of this species based on the specimens collected from Atlantic coast of North America. Specimens examined in the present study agree well with those of Chevreux and Fage (1925) and Bousefield (1973)'s except some morphological differences. Position of ventral tubercle on peduncular segment 5 in male antenna 2 observed in our specimen is located more proximally than Bousefield's (1973). In addition, Korean specimens lack the ventral spine on peduncular segment 5 of female antenna 2 which was possessed by those from other regions. These morphological differences observed in the present study seems to be local variation.

\section{ACKNOWLEDGEMENTS}

This research was supported by a grant (no. 2006-421) from the Ministry of Environment of the Korean Government.

\section{REFERENCES}

Barnard, J.L. and G.S. Karaman, 1991. The families and genera of marine gammaridean Amphipoda (except marine gammaroids). Rec. Austral. Mus., Suppl. 13, Parts 1 \& 2, pp. 1866.

Bousefield, E.L., 1973. Shallow-water gammaridean Amphipoda of New England. Cornell University Press, Ithaca, New York, pp. 1-312.

Bousefield, E.L. and P.M. Hoover, 1997. The amphipod superfamily Corophioidea on the Pacific Coast of North America. Part V. Family Corophiidae. Corophiinae, new subfamily. Sysematics and distributional ecology. Amphipacifica, 2(3): 67-139.

Chevreux, E., 1908. Sur trois nouveaux amphipodes Mediterraneens appartenant au genre Corophium Latreille. Bull. Soc. Zool. France, 33: 69-75.

Chevreux, E. and L. Fage, 1925. Amphipodes. Fauna de France, 9: 1-488.

Irie, H., 1957. Pelagic amphipods in the western seas of Kyushu. Bull. Fac. Fish., Nagasaki Univ., 5: 8-12.

Iire, H., 1958. Pelagic amphipods in Omura Bay. Bull. Fac. Fish., Nagasaki Univ., 6: 106-108.

Schellenberg, A., 1928. Report on the Amphipoda. Zoological results of Cambridge Expedition to the Suez Canal, 1924. Trans. Zool. Soc. London, 22: 633-692.

Shoemaker, C.R., 1934. The amphipod genus Corophium on the east coast of America. Proc. Biol. Soc. Washington, 47: 23-32.

Received October 5, 2007 Accepted November 7, 2007 